DOI: https://doi.org/10.24127/ajpm.v10i3.4064

\title{
THE EFFECT OF HYBRID LEARNING AND ENJOYMENT LEARNING IN INCREASING ADVANCE MATHEMATICAL THINKING
}

\author{
Ayu Aristika ${ }^{1 *}$, Darhim ${ }^{2}$, Dadang Juandi ${ }^{3}$, Kusnandi ${ }^{4}$ \\ ${ }^{1 *, 2,3,4}$ Universitas Pendidikan Indonesia, Bandung, Indonesia \\ ${ }^{*}$ Corresponding author. \\ E-mail: ayuaristika@upi.edu ${ }^{1 *}$
}

Received 28 July 2021; Received in revised form 13 September 2021; Accepted 27 September 2021

\begin{abstract}
AMT ability is one of the skills that is a priority to be developed in learning mathematics in universities. This research aims to test the effect of hybrid learning and enjoyment learning in improving Advance Mathematical Thinking of prospective teacher students moderated by learning style. This research is a quantitative research that aims to examine the effect of the independent variable on the dependent variable. The sample in this study is conducted by purposive sampling based on certain criteria. The research data is obtained by distributing questionnaires to the mathematics education program student at University X in Bandung City. The data collected is analyzed by path analysis assisted by Smart PLS application. Smart PLS analysis in this study is carried out in 2 stages which are the analysis of the outer model and the inner model. Analysis of the inner model is aimed at (1) testing the validity and reliability of the instrument and (2) performing the r-square test to determine the percentage of influence. The test results show that learning enjoyment and hybrid learning have a significant positive effect on advanced mathematics learning. The learning styles in this study have not been able to moderate the relationship between hybrid learning and enjoy learning on Advance Mathematical Thinking. Hybrid learning can be used as an alternative or learning solution in improving advanced mathematical learning.
\end{abstract}

Keywords: Hybrid learning; advance mathematical thinking; enjoyment learning; prospective teacher students; learning style.

\begin{abstract}
Abstrak
Kemampuan AMT merupakan salah satu kemampuan matematis yang menjadi prioritas untuk dikembangkan dalam pembelajaran matematika di perguruan tinggi. Penelitian Ini Bertujuan Untuk Menguji Pengaruh Hybrid Learning dan Enjoyment Learning Dalam Meningkatkan Berpikir Advance Mathematical Thinking of Prospective Teacher Students dimoderasi Gaya Belajar. Penelitian ini merupakan penelitian kuantitatif yang bertjuan untuk menguji pengaruh variabel independen terhadap variabel dependen. Sample dalam penelitian ini dilakukan dengan purposive sampling dengan berdasarkan beberapa kriteria tertentu. Data penelitian diperoleh dengan menyebar quesioner pada mahasiswa program studi Pendidikan Matematika di Universitas X di Kota Bandung. Data yang terkumpul dianalisa dengan analisis path berbantuan aplikasi Smart PLS. Analisis smart PLS pada penelitian ini dilakukan dengan 2 tahapan yaitu analisa outer model dan inner model. Analisa inner model untuk 1) menguji validitas dan reliabilitas instrumen serta 2) melakukan uji $r$ square untuk mengetahui presentase pengaruh. Hasil pengujian hipotesis menunjukkan bahwa enjoyment learning dan Hybrid learning berpengaruh secara positif signifikan terhadap Advance mathematic learning. Adapun, gaya belajar dalam penelitianini belum mampu memoderasi hubungan hybrid learning dan enjoyment learning terhadap Advance Mathematic Thinking. Hybrid learning dapat dapat dijadikan alternatif atau solusi pembelajaran dalam meningkatkan Advance Mathematic Learning.
\end{abstract}

Kata kunci: Pembelajaran hibrid; advance mathematical thinking; kenikmatan belajar; mahasiswa calon guru; gaya belajar.

This is an open access article under the Creative Commons Attribution 4.0 International License 
DOI: https://doi.org/10.24127/ajpm.v10i3.4064

\section{INTRODUCTION}

Mathematics cannot be separated from everyday life. Therefore, mathematics is taught formally from elementary school to college level (Kilpatrick, 2020). College mathematics is generally more complex than schoollevel mathematics; it is because the material provided is more abstract. Therefore, students of the mathematics education study program are expected to be able to construct and find mathematical definitions/concepts independently, prove logically, and be able to develop their mathematical abilities further (Valente, 2020). This is very important for students in completing college level mathematics lecture assignments, espe-cially advanced mathematics courses (Maya \& Sumarmo, 2011). To realize these expectations, students' mathema-tical thinking skills must be developed and linked to mathematical thinking in order to form Advance Mathematical Thinking skills that focus more on formal definitions, logical deduction, and creative thinking (Minarni \& Napitupulu, 2017).

AMT ability is one of the mathematical abilities that is a priority to be developed in learning mathematics in universities. However, based on the results of a survey conducted by Schoenfeld (2017) on Tennesse University of Technology students who had passed the calculus course, it turned out that not a single student was able to answer the questions correctly. In addition, Schoenfeld (2017b) also conducted tests on new students who excelled in high school and found that many of them had misconceptions about mathematical concepts. This is because students tend to have difficulty in obtaining the essence of abstract mathematical concepts and difficulties in constructing the expected general form (Kashefi, Ismail, \& Yusof, 2010). The first problem faced by students in AMT ability is representation ability. The ability of representation can help students understand, communicate, and relate mathematical concepts in various forms. The problem of representation is seen from students who tend to use symbolic representations without paying attention to other forms of representation (Kuswardi et al. 2020). The study of Bistari (2010) shows that most students still have difficulty in using various mathematical representations to explain mathematical ideas and solve mathematical problems. The next problem is abstraction which is a basic process in the form of mathematics. According to Yao \& Manouchehri (2020) abstraction and representation are two complementary processes. However, abstraction turns out to be one of the causes of students failing in the mathematics learning process. This is because students tend to have difficulty in obtaining the essence of abstract mathematical concepts. In line with Faradillah \& Humaira (2021) who said that students generally still have difficulty in constructing the expected general form.

A survey indicates that developing AMT's ability to solve problems requires an appropriate learning model (Jacobs \& Empson, 2016). The learning model must be active and support student involvement to understand concepts and think creatively in calculus courses. The hybrid learning model is an innovative learning model that utilizes information and communication technology (Nugraha, Sudiatmi, \& Suswandari, 2020). The hybrid learning model has developed around 2000 and has been 
used in several countries such as North America, England, and Australia universities and training institutions. This learning model has several advantages, namely using learning technology such as computer media, iPhone, TV, video conferencing, picture and sound, multimedia presentations, weblogs, and social media (Suhery, Putra, \& Jasmalinda, 2020).

According to Chirino-Barceló \& Molina (2011), hybrid learning is a knowledge and skill acquisition process (learner-centered) developed with an instructional design that integrates digital (internet and mobile), printed, recorded, and traditional face-to-face classroom activities in a way that planned, valuable pedagogical. Hybrid learning also facilitates students to direct their own learning process by choosing methods with available learning materials that best suit their individual characteristics and needs that are oriented towards achieving curriculum learning objectives. Marković et al. (2011) asserted that hybrid learning is a learning model that integrates innovation and technological advances through an online learning system with the interaction and participation of traditional learning models.

Learning designed with a hybrid learning approach is also possible to influence students' metacognitive awareness (Purmadi \& Hadi, 2018). Hybrid learning has advantages because in addition to using a face-to-face approach, this approach also uses ICT, both mobile and non-mobile technology. This innovation can increase the effectiveness of teaching and learning (De-Marcos et al., 2010). The use of the internet must be integrated into the higher education system. The use of information and communication technology in learning activities has an impact on the students learning process and outcomes. Computer-assisted learning can improve interactive and communicative aspects (Peterson, 2010). Hybrid Learning is an approach that seeks to incorporate the best benefits from "old" and "new" teaching methods so that the quality of learning developed is of optimal quality that better than just face-to-face quality or just online learning activities online (Mufidah, Salamah, Muthoharoh, \& Irfan Islamy, 2019).

In addition to Hybrid learning, another factor that also affects the ability of MTA is enjoyment learning. One of the importances of fun learning is being able to speed up the process of teaching and learning activities. Meanwhile, the impact of learning that occurs in an unpleasant atmosphere will be able to cause the process of teaching and learning activities to be hampered and even possible to experience termination (Hwang, 2018).

Apart from implementing Hybrid learning and enjoyment learning, Kohnen (2010) says that the key to succeed in learning and work is knowing each person's unique learning or work style, accepting one's own strengths and weaknesses and as much as possible adjusting personal preferences in each learning, study or work situation. In following the learning process, each student has a different learning style from one student to another. Lecturers in teaching must pay attention to student learning styles. This is because in every teaching, its effectiveness will depend on the way or style of student learning, in addition to their personal nature and intellectual abilities (Thomas F. Hawk \& Amit J. Shah, 2010).

The learning styles of students can be observed from the multiple 
intelligences they have and each student has their own dominant intelligence. Zulfa, et al (2019) said that only students who succeed in learning in class because they have a learning style is in accordance with the teaching style applied by the lecturer in the classroom. Conversely, students have difficulty in participating in classroom learning because they have other learning styles, which are not in accordance with the teaching styles applied in the classroom. Research conducted by Dettori (2015) resulted in a significant difference in learning styles between male and female students. Male students are more likely to have convergent learning styles, while female students are more likely to have divergent learning styles. Research by Bailey (2020) found that learning styles significantly influence learning outcomes.

A research regarding MTA was conducted by Elliott et al., (2011) who tried to find out the difference in MTA between the control group and the experimental group given treatment in the form of a metacognitive skills approach. The results of their research show that the metacognitive approach is proven to be able to increase MTA.

The development of Advance Mathematical Thinking is generally emphasized for advanced mathematics courses such as algebraic structures, real analysis, probability theory, and theoretical statistics (Mathematical Statistics). The questions answered by students were then analyzed with indicators (representation, abstraction, creative thinking, and evidence) (Kuswardi et al., 2020).

In previous studies, the improvement of MTA ability was still carried out by giving questions, which were more focused on results. Learning with assignments is still limited to space and time which requires educators and students to be in the same space and time; thus, to get more accurate and upto-date research results, researchers are interested in further researching about MTA through the application of Hybrid learning moderated by learning styles. In this study, both the variables studied and the MTA development process was developed (Dwijonagoro \& Suparno, 2019).

Several research results conducted by Damo \& Padagas (2020) found that the hybrid learning model has the potential to improve students' mathematical abilities and student learning outcomes. In teaching mathematics, a teacher in presenting learning with a hybrid learning model must pay attention to several things prerequisites which is the requirement to master and know the IT developing (Pavlidou, Dragicevic, \& Tsui, 2021). In addition, the teacher must also have teaching skills, present face-to-face learning content, and have knowledge and skills in developing computer-based learning resources. In designing mathematics learning using a hybrid learning model, it is also necessary to set up thought that students can learn anywhere, anytime, and with anyone (for example, students can study with teachers, experts, friends, family, communities) through learning resources which varies such as textbooks, internet, $\mathrm{CD}$ room, radio, tape, $\mathrm{TV}$, etc. The interesting thing in this hybrid learning system is that it combines two kinds of choices that will play a big role in the lecture process which is teacher (instructor-led) or student (learner-led).

Currently, the development of hybrid learning is very much, all of which comes from the combination of one or more models, methods, or media; thus, students will learn something 
different and new to analyze and study. This will spur students to think critically because of the demands for independent learning when running online classes (Malti et al., 2017).

The hybrid learning model in this study was chosen because it combines modified problem-based learning with the Science, Technology, Engineering, and Mathematics (STEM) approach and uses the E-Learning system in learning; where this hybrid learning model can provide opportunities for prospective teachers to increase creativity and representational skills in mastering concepts by applying the Project-Based Learning model and the STEM approach used by Laboy-Rush (2011) and combined with the use of the Edmodo application in learning for prospective teachers. Edmodo app is one of the social media applications that has more functions to help lecturers to manage a system that provides features to connect students and manage student activities easily. This research aims to test the effect of hybrid learning and enjoyment learning in improving Advance Mathematical Thinking of

Table 1. Indicators of variable

\begin{tabular}{|c|c|c|}
\hline Variable & Dimension & Indicator \\
\hline \multirow{9}{*}{$\begin{array}{l}\text { Advance } \\
\text { Mathenatic } \\
\text { Thinking }\end{array}$} & Representation & - Uncovering mathematical ideas \\
\hline & & - Communicating the results of work in a certain \\
\hline & & $\begin{array}{l}\text { way as a result of the interpretation of his mind, } \\
\text { such as arithmetic symbol representation, } \\
\text { language/verbal representation, and image or } \\
\text { graphic representation. }\end{array}$ \\
\hline & Abstraction & $\begin{array}{l}\text { - Generalizing and generating/inducing special } \\
\text { forms in mathematical concepts to be able to } \\
\text { identify similarities }\end{array}$ \\
\hline & & $\begin{array}{l}\text { - Synthesizing/combining parts of mathematical } \\
\text { concepts to form a whole. }\end{array}$ \\
\hline & $\begin{array}{l}\text { Mathematical } \\
\text { creative thinking }\end{array}$ & $\begin{array}{l}\text { - Fluency: generating amounts of ideas in } \\
\text { different categories }\end{array}$ \\
\hline & & - Originality: having new ideas \\
\hline & & - Elaboration: solving problems in detail \\
\hline & Compiling & - Constructing proofs that have been obtained \\
\hline
\end{tabular}

prospective teacher students moderated learning style.

\section{METHOD}

The research approach used in this study is a quantitative approach (Sugiono, 2016). Quantitative research method aims to test the established hypotheses. The quantitative method is in the form of numbers derived from measurements using a scale on the variables in the study. Respondents in this study are students of the Mathematics Education Study Program at University $\mathrm{X}$ in Bandung City. The sample is determined by purposive sampling technique with the following criteria.

1. Student at University X;

2. Mathematics Education study program students;

3. Students who are in the semester of 2020/2021 receiving a multivariable calculus course.

The data in this study are obtained using a questionnaire with a Likert scale $(5,4,3,2,1)$. The indicators of variable used in this study is displayed in Table 1 . 
DOI: https://doi.org/10.24127/ajpm.v10i3.4064

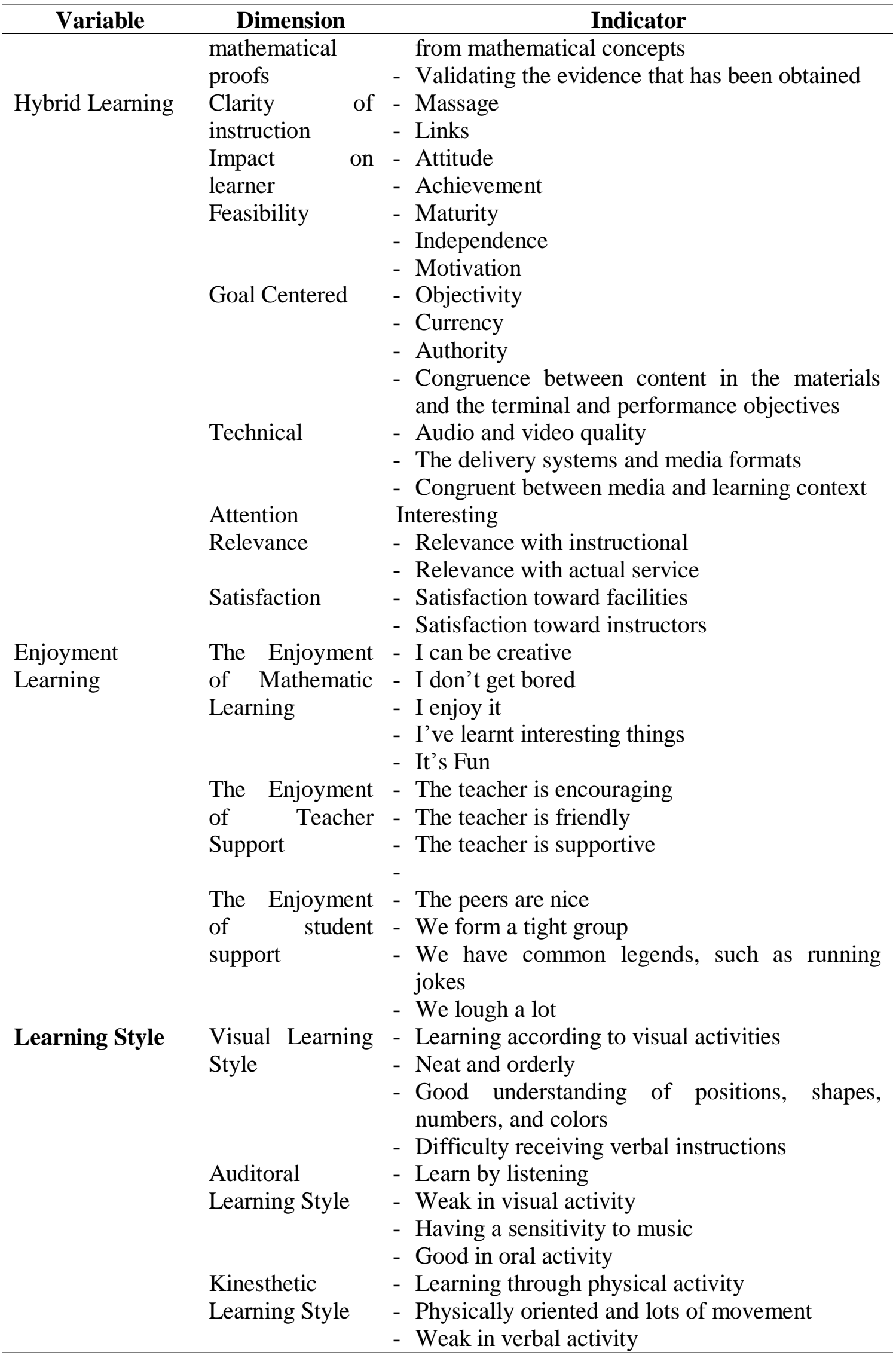


DOI: https://doi.org/10.24127/ajpm.v10i3.4064

The data analysis used a structural approach to the Equation Model (SEM) assisted by the smart PLS application. The stages of data analysis in this study are defined in the following.

\section{Outer Model Analysis \\ Validity and Reliability Test}

Validity and reliability tests are carried out to ensure that the measurement used is feasible to be used as a measurement (valid and reliable). Testing the validity and reliability can be perceived from explanation in the following.

a. Convergent Validity is an indicator assessed based on the correlation between the item score/component score with the construct score, seen from the standardized loading factor that describes the magnitude of the correlation between each measurement item (indicator) and its construct. Individual reflexive measures are said to be high if the correlation is $>0.7$.

b. Discriminant Validity is a measurement model with reflexive indicators assessed based on the crossloading of measurements with constructs of discriminant validity, namely comparing the value of the squareroot of average variance extracted (AVE), the instrument is declared valid if it has an AVE score of $>0.5$

c. Composite reliability is an indicator to measure a construct seen in the view of latent variable coefficients. In this measurement, if the value achieved is $>0.70$, it can be concluded that the construct has high reliability.

d. Cronbach Alpha is a reliability test carried out to strengthen the results of composite reliability. A variable can be declared reliable if it has
Cronbach alpha value of $>0.7$. The Table 2 presents of the instrument testing in this study.

Table 2. Instrument testing

\begin{tabular}{ll}
\multicolumn{1}{c}{ Test } & \multicolumn{1}{c}{ Test used } \\
\multicolumn{1}{c}{ Instrument } & \\
\hline Validity Test & Convergent Validity \\
& AVE \\
Reliability & Cronbach Alpha \\
Test & Composite Reliability \\
\hline
\end{tabular}

\section{R-Square Test}

R-square for the dependent construct is used to assess the effect of certain independent latent variables on the dependent latent variable which shows the presentation of the magnitude of the effect.

\section{Inner Model Analysis}

The Inner Model Analysis or commonly called the Structural Model is used to predict the causal relationship between the variables tested in the model. The analysis of the inner model in testing using Smart PLS is done by testing the hypothesis. In testing the hypothesis, it can be seen from the $t$ statistical value and probability value. To test the hypothesis, it uses statistical values; for alpha 5\%, the t-statistic value used is 1.96 , while the beta score is used to determine the direction of the influence of the relationship between variables. The criteria for acceptance/rejection of the hypothesis are:

$\mathrm{Ha}=\mathrm{t}$-statistic $>1.96(\mathrm{p}$-value $<0.05)$.

Ho $=$ t-statistic $<1.96($ p-values $>0.05)$

\section{RESULT AND DISCUSSION}

Partial Least Square analysis in this study was carried out using the help of SmartPls software 3.2.9 version. According to Götz et al. (2010), in general, the evaluation of the model in 
DOI: https://doi.org/10.24127/ajpm.v10i3.4064

the Partial Least Square analysis is the evaluation of the measurement model (outer model) and evaluation of the structural model (inner model).

\section{Evaluation of the Measurement Model (Outer Model) Validity test}

Validity test is used to measure the validity of a questionnaire. In this research, validity testing is carried out using convergent validity and AVE. The instrument is declared valid if the AVE value gains $>0.5$ and the outer loading value is $>0.7$. The outer model test results can be seen in Figure 1 and the results of the validity test are described in the Table 3.

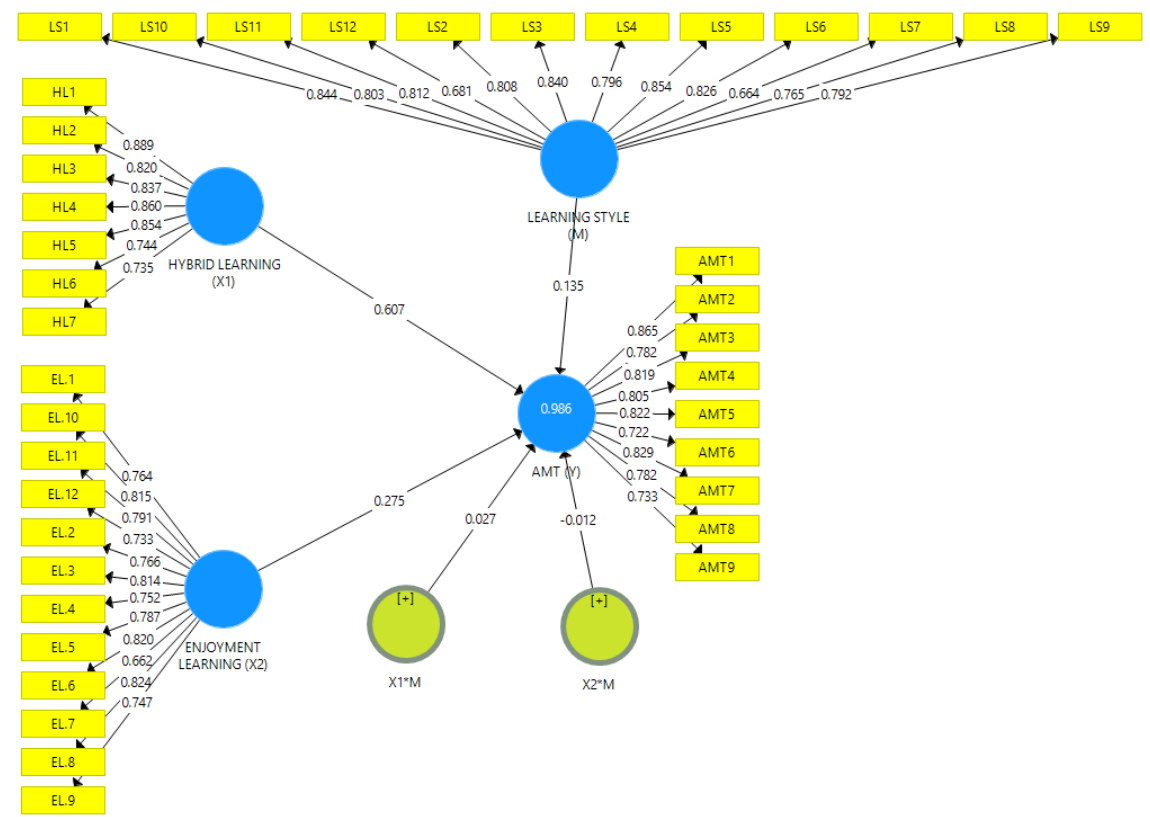

Figure 1. The outer model test results

Table 3. Convergent validity measurement value

\begin{tabular}{|c|c|c|c|c|}
\hline Variable & Indicator & Outer Loading & VE & Result \\
\hline Advance & AMT1 & 0.865 & \multirow{9}{*}{.563} & Valid \\
\hline Mathematical & AMT2 & 0.782 & & Valid \\
\hline \multirow[t]{7}{*}{ Thinking } & AMT3 & 0.819 & & Valid \\
\hline & AMT4 & 0.805 & & Valid \\
\hline & AMT5 & 0.822 & & Valid \\
\hline & AMT6 & 0.722 & & Valid \\
\hline & AMT7 & 0.829 & & Valid \\
\hline & АMT8 & 0.782 & & Valid \\
\hline & AMT9 & 0.733 & & Valid \\
\hline \multirow[t]{5}{*}{ Hybrid Learning } & HL1 & 0.889 & \multirow{5}{*}{.527} & Valid \\
\hline & HL2 & 0.820 & & Valid \\
\hline & HL3 & 0.837 & & Valid \\
\hline & HL4 & 0.860 & & Valid \\
\hline & HL5 & 0.854 & & Valid \\
\hline
\end{tabular}


DOI: https://doi.org/10.24127/ajpm.v10i3.4064

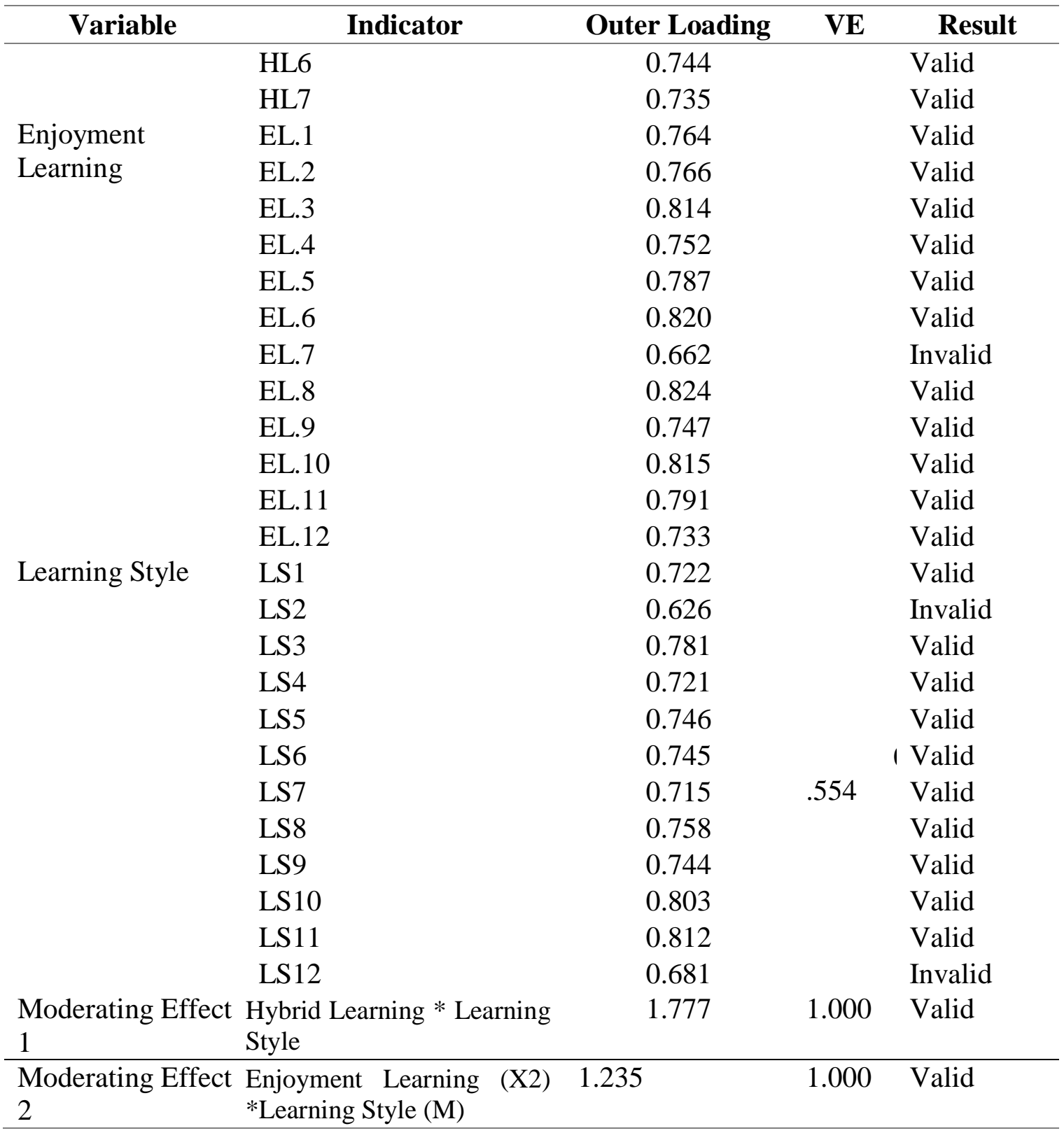

According to the measurement results of the outer loading on the reflective indicator, it is known that there are 3 indicators that are not valid because they have an outer loading value of less than 0.7 (outer loading < 0.7 ), so that the researcher omitted this indicator.

\section{Reliability Test}

An indicator is considered reliable if it has a correlation value above 0.70 . However, at the research stage of the scale development stage, a loading of 0.50 to 0.60 is still acceptable (Ghozali, 2013). The results of the reliability test in this study can be seen in the Table 4 .

\section{Measurement of the Coefficient of Determination (R2)}

The R-Square Coefficient determination (R-Square) test is used to measure how much the endogenous variable is influenced by other variables. Based on the data analysis carried out through the use of the smartPLS program, the R- 
DOI: https://doi.org/10.24127/ajpm.v10i3.4064

Square value is 0,986 and R-Square Adjusted value is 0,985 .

Based on the r-square value in the hybrid learning influence model on Advance Mathematical Thinking moderated by learning style, the rsquare value is 0.986 . These results indicate that the hybrid learning variable is able to explain the Advance Mathematical Thinking variable by $98.6 \%$ while the remaining $1.4 \%$ is influenced by variables that are not explained in the study.

Table 4. Reliability test result

\begin{tabular}{lccl}
\hline & Cronbach Alpha & Composite Reliability & Result \\
\hline AMT (Y) & 0.928 & 0.940 & Reliable \\
Enjoyment Learning (X2) & 0.939 & 0.947 & Reliable \\
Hybrid Learning (X1) & 0.919 & 0.935 & Reliable \\
Learning Style (M) & 0.946 & 0.953 & Reliable \\
X1*M & 1.000 & 1.000 & Reliable \\
X2*M & 1.000 & 1.000 & Reliable \\
\hline
\end{tabular}

Table 6. Hypothesis test

\begin{tabular}{lcclc}
\hline & $\boldsymbol{\beta}$ & T-Statistics $(\mid \mathbf{O} /$ STDEV $)$ & P-Values & Result \\
\hline Enjoyment Learning (X2) -> AMT (Y) & 0.324 & 8.620 & 0.000 & PS \\
\hline Hybrid Learning (X1) -> AMT (Y) & 0.444 & 5.187 & 0.000 & PS \\
\hline X1*M -> AMT (Y) & 0.066 & 1.146 & 0.252 & PS \\
\hline X2*M -> AMT (Y) & -0.057 & 0.925 & 0.355 & PS \\
\hline
\end{tabular}

PS: Positively Significant

\section{Evaluation of the Structural Model (Inner Model)}

Based on the data processing that has been done, the results can be used to answer the hypothesis in this study. Hypothesis testing in this study was carried out by looking at the t-statistics score and the p-values score.

Beside t-statistics and p-values, the hypothesis is also carried out by looking at Beta Score. Beta score describes the direction of the relationship accepting/rejecting the determined hypothesis based on criteria:

$\mathrm{Ha}=\mathrm{t}$-statistic $>1.96$ (p-values < 0.05). $\mathrm{HO}=\mathrm{t}$-statistic $<1.96$ (p-values $>0.05$ )

The results of hypothesis testing obtained in this study through the inner model can be seen in Table 6 .

\section{Effect of Hybrid Learning on Advance Mathematical Thinking}

The results of hypothesis testing show that the effect of hybrid learning on Advance Mathematical Thinking has a path coefficient value of 0.324 , tstatistic value of 8.620 , and $p$-value value of 0.000 . The $t$-statistic value is greater than the t-table $(8.620>1.96)$ and the p-value is 0.000 or smaller than the $5 \%$ alpha standard $(0.000<0.05)$; a positive score indicates that there is a significant positive effect of hybrid learning on Advance Mathematical Thinking. In other words, better hybrid learning is able to improve Advance Mathematical Thinking or the first hypothesis (H1) is accepted. These results are consistent with the findings of Chirino-Barceló \& Molina (2011) 
where hybrid learning has a significant positive effect on learning success.

Advance Mathematical Thinking (AMT) is an ability that includes representation, abstraction and connecting representations with abstractions, mathematical creative thinking, and compiling mathematical proofs (Suryana, 2012). Advance Mathematical Thinking can be improved through hybrid learning-based learning. As explained by Hung, Chang, \& Lin (2016) e-learning that is suitable for school conditions in our country is blended learning, where one of the main problems of e-Learning learning is internet connection. Blended learning system is created as a solution to anticipate this problem by collaborating face-to-face learning with online learning.

\section{Effect of Enjoyment Learning on Advance Mathematical Thinking}

The results of hypothesis testing show that the effect of enjoyment learning on Advance Mathematical Thinking has a t-statistic of 5.187 and a $\mathrm{p}$-value of 0.000 . The t-statistic value is greater than the t-table $(5.187>1.96)$ while the p-value is 0.000 or smaller than the $5 \%$ alpha standard $(0.000<0.05)$ with a positive score indicating that there is a significant positive effect of enjoyment learning on Advance Mathematical Thinking. In other words, the better enjoyment learning can improve Advance Mathematical Thinking or the first hypothesis (H2) is accepted. These results are in accordance with the findings of Zazkis \& Leikin (2010).

One of the strategies that can be used to develop AMT is the APOS strategy where this strategy is able to encourage students to be actively involved. The active involvement of students in a discussion is one indication of enjoyment learning. Gilakjani \& Ahmadi (2011) state that by listening to what others have found and discussing it, students are enabled to improve the strategies they find themselves. Thus, the interaction allows students to reflect which will ultimately encourage them to gain a higher understanding than before. Furthermore, research by Fouze \& Amit (2018) found that AMT improvement can be done through the teacher's role in fostering enjoyment learning through completion divergent problem based on teacher scaffolding leveling.

\section{Effect of Hybrid Learning on Advance Mathematical Thinking Moderated by Learning Style}

The results of hypothesis testing the effect of hybrid learning on Advance Mathematical Thinking moderated by learning style has a tstatistic value of 5.187 and a p-value score of 0.252 ; the t-statistic value is smaller than t-table $(1,146<1.96)$ while $\mathrm{p}$-value is 0.252 or greater than standard alpha $5 \%(0.252>0.05)$ with a positive score indicates that the learning style is not able to moderate the relationship between hybrid learning and advance mathematical learning. In other words, without a learning style, the application of hybrid learning has been able to have a direct effect on improving Advance Mathematical Thinking or the third hypothesis (H3) is rejected. This result rejects the findings of Gurpinar et al., (2010).

In learning mathematics, the teacher provides opportunities for students to carry out activities of finding and investigating patterns and to determine relationships. Activities can be carried out through experiments to find sequences, differences, compari- 
DOI: https://doi.org/10.24127/ajpm.v10i3.4064

sons, groupings, etc. and provide opportunities for students to find relationships between understanding one another. Mathematics material is increasingly difficult to learn. (Cheng, Ritzhaupt, \& Antonenko, 2019) suggests that mathematics learning is often rated negatively by students and they have considerable difficulty in several mathematical processes such as reasoning, non-routine problem solving and proving.

AMT improvement needs to be done flexibly, one of which is through the application of hybrid learning; thus, this ability can be mastered by students maximumly. It causes a certain learning style tendency not able to affect the mastery of AMT. AMT improvement must integrate the three learning styles, both auditory visual and kinesthetic.

\section{Effect of Enjoyment Learning on Advance Mathematical Thinking Moderated by Learning Style}

The results of hypothesis testing the effect of enjoyment learning on Advance Mathematical Thinking moderated by learning style has a tstatistic of 0.925 and p-value of 0.355 ; the $\mathrm{t}$-statistic value is smaller than the $\mathrm{t}$ table $(0.925<1.96)$ while the $\mathrm{p}$-value is 0.355 or greater than the $5 \%$ alpha standard $(0.355>0.05)$ with a negative score indicating that learning styles are not able to moderate the relationship between enjoyment learning and advance mathematical learning. In other words, without a learning style, the application of enjoyment learning has been able to have a direct effect on improving Advance Mathematical Thinking or the third hypothesis (H4) is rejected. This result rejects the findings (Cimermanová, 2018).

Mathematics in school can be viewed as a combination of visual representations, including geometry and graphs, together with computation and symbolic manipulation; whereas, mathematics in college shifts towards formal frameworks, axiomatic systems and mathematical proofs.

Advance Mathematical Thinking is an ability that includes representation, abstraction, connecting representations and abstractions, mathematical creative thinking, and mathematical proving. The change from elementary thinking to advance mathematical thinking involves a significant transition from describing to defining, from convincing to logically proving based on a definition.

The learning method used is lecture. The lecture method is very suitable for the auditory type because the learning style is by listening. However, visual and kinesthetic learning styles are not suitable if they are not balanced with a variety of other learning methods that support their learning styles. Therefore, the learning style is not able to moderate the role of enjoyment learning on increasing student AMT.

Enjoyment learning can lead students to be able to understand mathematical objects and the relationship between one mathematical object and another. In its implementation, lecturers must encourage students to do transactive reasoning such as criticizing, explaining, clarifying, justifying, and elaborating an idea proposed whether initiated by students or lecturers.

\section{CONCLUSION AND SUGGESTION}

According to the results of hypothesis testing, it is known that enjoyment learning and hybrid learning have a significant positive effect on Advance Mathematical Learning. Meanwhile, the learning style in this 
study has not been able to moderate the relationship between hybrid learning and enjoyment learning on Advance Mathematical Thinking. Hybrid learning can be used as an alternative or learning solution in improving Advance Mathematical Learning. In addition to the application of hybrid learning, the improvement of AMT can be done from the role of lecturers as teachers in fostering enjoyment learning in delivering lectures.

\section{REFERENCES}

Bailey, L. (2020). Comparing Students' Learning Outcomes and Satisfaction in Online, Hybrid and Face-To-Face Education Courses. Dissertation, Temple University.

Bistari. (2010). Pengembangan Kemandirian Belajar Berbasis Nilai Untuk Meningkatkan Komunikasi Matematik. Jurnal Pendidikan Matematika Dan IPA.

Cheng, L., Ritzhaupt, A. D., \& Antonenko, P. (2019). Effects of the flipped classroom instructional strategy on students' learning outcomes: a meta-analysis. Educational Technology Research and Development. https://doi.org/10.1007/s11423018-9633-7

Chirino-Barceló, V., \& Molina, A. (2011). Critical Factors in Defining the Mobile Learning Model: An Innovative Process for Hybrid Learning at the Tecnologico de Monterrey, a Mexican University. Handbook of Research on Mobility and Computing, 1, 774-792. https://doi.org/10.4018/978-160960-042-6

Cimermanová, I. (2018). The effect of learning styles on academic achievement in different forms of teaching. International Journal of
Instruction.

https://doi.org/10.12973/iji.2018.1

$1316 \mathrm{a}$

Damo, L. E., \& Padagas, R. C. (2020). Can hybrid learning supplant the brick-and-stone classroom in teaching "strategies for academic success in college"? A focus assessment study. Universal Journal of Educational Research. https://doi.org/10.13189/ujer.2020. 080507

De-Marcos, L., Hilera, J. R., Barchino, R., Jiménez, L., Martínez, J. J., Gutiérrez, J. A., ... Otón, S. (2010). An experiment for improving students performance in secondary and tertiary education by means of m-learning autoassessment. Computers and Education.

https://doi.org/10.1016/j.compedu. 2010.05.003

Dettori, G. (2015). Online and hybrid learning design fundamentals. British Journal of Educational Technology.

Dwijonagoro, S., \& Suparno, S. (2019). Pranatacara learning: Modeling, mind mapping, e-learning, or hybrid learning? Cakrawala Pendidikan.

https://doi.org/10.21831/cp.v38i1.2 3034

Elliott, R., McKinley, S., \& Cistulli, P. (2011). The quality and duration of sleep in the intensive care setting: An integrative review. International Journal of Nursing Studies. https://doi.org/10.1016/j.ijnurstu.2 010.11 .006

Evans, J. (2002). Adults' Mathematical Thinking and Emotions. In Adults' Mathematical Thinking and Emotions. https://doi.org/10.4324/978020318 
DOI: https://doi.org/10.24127/ajpm.v10i3.4064

5896

Faradillah, A., \& Humaira, T. (2021). Mathematical Critical Thinking Skills Senior High School Student Based on Mathematical Resilience and Domicile. Jurnal Cendekia: Jurnal Pendidikan Matematika. https://doi.org/10.31004/cendekia. v5i2.682

Fouze, A. Q., \& Amit, M. (2018). Development of mathematical thinking through integration of ethnomathematic folklore game in math instruction. Eurasia Journal of Mathematics, Science and Technology Education. https://doi.org/10.12973/ejmste/80 626

Ghozali, I. (2013). Ghozali, Imam (2013). Aplikasi Analisis Multivariate Dengan Program IBM SPSS 21Update PLS Regresi. Semarang: Badan Penerbit Universitas Diponegoro.

Gilakjani, A. P., \& Ahmadi, M. R. (2011). A Study of Factors Affecting EFL Learners' English Listening Comprehension and the Strategies for Improvement. Journal of Language Teaching and Research.

https://doi.org/10.4304/jltr.2.5.977988

Gurpinar, E., Alimoglu, M. K., Mamakli, S., \& Aktekin, M. (2010). Can learning style predict student satisfaction with different instruction methods and academic achievement in medical education? American Journal of Physiology Advances in Physiology Education. https://doi.org/10.1152/advan.0007 5.2010

Hawk, T. F., \& Shah, A. J. (2007). Using Learning Style Instruments to Enhance Student Learning. Decision Sciences Journal of
Innovative

Education.

https://doi.org/10.1111/j.1540-

4609.2007.00125.x

Hung, Y. H., Chang, R. I., \& Lin, C. F. (2016). Hybrid learning style identification and developing adaptive problem-solving learning activities. Computers in Human Behavior.

https://doi.org/10.1016/j.chb.2015. 07.004

Hwang, A. (2018). Online and Hybrid Learning. Journal of Management Education.

https://doi.org/10.1177/105256291 8777550

Jacobs, V. R., \& Empson, S. B. (2016). Responding to children's mathematical thinking in the moment: an emerging framework of teaching moves. ZDM Mathematics Education. https://doi.org/10.1007/s11858015-0717-0

Kashefi, H., Ismail, Z., \& Yusof, Y. M. (2010). Obstacles in the learning of two-variable functions through mathematical thinking approach. Procedia - Social and Behavioral Sciences.

https://doi.org/10.1016/j.sbspro.20 10.12.024

Kilpatrick, J. (2020). History of Research in Mathematics Education. In Encyclopedia of Mathematics Education. https://doi.org/10.1007/978-3-03015789-0_71

Kohnen, J. (2010). Strengths Based Leadership: Great Leaders, Teams, and Why People Follow. Quality Management Journal. https://doi.org/10.1080/10686967.2 010.11918263

Kuswardi, Y., Usodo, B., Sutopo, S., Chrisnawati, H. E., \& Nurhasanah, F. (2020). Advanced Mathematic 
DOI: https://doi.org/10.24127/ajpm.v10i3.4064

Thinking Ability Based on The Level of Student's Self-Trust in Learning Mathematic Discrete. Journal of Mathematics and Mathematics Education. https://doi.org/10.20961/jmme.v10 i2.47080

Laboy-Rush, D. (2011). Integrated STEM Education through ProjectBased Learning. Learning.Com, 38.

Malti, T., Beelmann, A., Noam, G. G., Sommer, S., Francis, I., Leeman, J., ... Rosenbloom, D. L. . (2017). Health Policy: Application for Nurses and Other Healthcare Professionals. Journal of Clinical Nursing.

Marković, D., Grgurović, B., \& Štrbac, S. (2011). The use of spatial data for segmentation of the postal service market. Technological and Economic Development of Economy. https://doi.org/10.3846/13928619.2 011.554016

Masters, K., \& Ellaway, R. (2008). eLearning in medical education Guide 32 Part 2: Technology, management and design. Medical Teacher. https://doi.org/10.1080/014215908 02108349

Maya, R., \& Sumarmo, U. (2011). Mathematical understanding and proving abilities: Experiment with undergraduate student by using modified moore learning approach. Journal on Mathematics Education.

https://doi.org/10.22342/jme.2.2.75 1.231-250

Minarni, A., \& Napitupulu, E. E. (2017). Developing Instruction Materials Based on Joyful PBL to Improve Students Mathematical Representation Ability.
International Education Studies. https://doi.org/10.5539/ies.v10n9p 23

Mufidah, N., Salamah, U., Muthoharoh, I., \& Irfan Islamy, M. (2019). Hybrid Learning Dalam Pembelajaran Kosa Kata Bahasa Arab Pada Anak Berbantuan Media Al-Mutho. Journal $A L$ MUDARRIS. https://doi.org/10.32478/almudarris.v2i1.227

Nugraha, S. A., Sudiatmi, T., \& Suswandari, M. (2020). STUDI Pengaruh Daring Learning Terhadap Hasil Belajar Matematika Kelas IV. Jurnal Inovasi Penelitian. https://doi.org/10.47492/jip.v1i3.7 4

Pavlidou, I., Dragicevic, N., \& Tsui, E. (2021). A multi-dimensional hybrid learning environment for business education: A knowledge dynamics perspective. Sustainability (Switzerland). https://doi.org/10.3390/su1307388 9

Peterson, M. (2010). Computerized games and simulations in computer-assisted language learning: A meta-analysis of research. Simulation and Gaming. https://doi.org/10.1177/104687810 9355684

Purmadi, A., \& Hadi, M. S. (2018). Pengembangan Kelas Daring Dengan Penerapan Hybrid Learning Menggunakan Chamilo Pada Matakuliah Pendidikan Kewarganegaraan. Edcomtech Jurnal Kajian Teknologi ....

Schoenfeld, A. H. (2017a). Uses of video in understanding and improving mathematical thinking and teaching. Journal of Mathematics Teacher Education. 
DOI: https://doi.org/10.24127/ajpm.v10i3.4064

https://doi.org/10.1007/s10857-

017-9381-3

Schoenfeld, A. H. (2017b). Uses of video in understanding and improving mathematical thinking and teaching Introduction: video in research and theory, and then in practice. Journal of Mathematics Teacher Education.

Sharples, M. (2006). Big issues in mobile learning. Learning Sciences Research Institute. https://doi.org/10.1007/978-14020-9827-7

Sugiono. (2016). Metode Penelitan Kuantitatif, kualitatif dan R\&D. Bandung: Alfabeta.

Suhery, Putra, T., \& Jasmalinda. (2020). Studi Pengaruh Daring Learning Terhadap Hasil Belajar Matematika Kelas Iv. Jurnal Inovasi Penelitian.

Suryana, A. (2012). Kemampuan berpikir matematis tingkat lanjut (Advanced mathematical thinking) dalam mata kuliah statistika matematika 1. Seminar Nasional Matematika Dan Pendidikan Matematika FMIPA UNY.

Thomas F. Hawk, \& Amit J. Shah. (2010). Using Learning Style Instruments to Enhance Student Learning. Sciences Journal of Innovative Education.

Tsitsia, B. Y., \& Kabbah, S. K. (2020). Trainee-Teachers' Perceptions on Traditional, Online And Hybrid Learning Modes of Mathematics Education in Ghana. African Journal of Education and Practice. https://doi.org/10.47604/ajep.1185

Valente, W. R. (2020). The GHEMAT Brasil and the collective research in history of mathematics education. Historia y Memoria de La Educacion. https://doi.org/10.5944/hme.11.202
0.24266

Yao, X., \& Manouchehri, A. (2020). Teacher interventions for advancing students' mathematical understanding. Education Sciences. https://doi.org/10.3390/educsci100 60164

Zazkis, R., \& Leikin, R. (2010). Advanced mathematical knowledge in teaching practice: Perceptions of secondary mathematics teachers. Mathematical Thinking and Learning. https://doi.org/10.1080/109860610 03786349

Zulfa, I., Kusairi, S., Latifah, E., \& Jauhariyah, M. N. R. (2019). Analysis of student's conceptual understanding on the work and energy of online hybrid learning. Journal of Physics: Conference Series. https://doi.org/10.1088/17426596/1171/1/012045 